\section{PORTAL VENOUS CATECHOL AMINES IN PORTAI. HYPERTENSION}

JoHN H. SIEGEL

M.D. Johns Hopkins

TiMOTHY S. HARRISON

M.D. Johns Hopkins

ASSISTANT PROFESSOR

\section{DEPARTMENT OF SURGERY, THE UNIVERSITY OF MICHIGAN} MEDICAL SCHOOL, ANN ARBOR, MICHIGAN, U.S.A.

PORTAL hypertension is generally looked upon as a result of obstruction to the portal vein, secondary to hepatic scarring and regeneration resulting from various parenchymal liver disorders. Less often, the obstruction follows thrombosis of the portal vein. But there remains a small group of patients with clear-cut evidence of portal hypertension in whom the portal vein is normal and the liver seems suprisingly free of disease (Tisdale et al. 1959). Latterly, Shaldon and his colleagues (1961, 1962), using a bioassay method found that the level of adrenaline and noradrenaline in the portal venous blood was raised in patients with portal hypertension. We tried to confirm and extend these findings by determining the catechol amines in plasma fluorometrically (Cohen and Goldenberg 1957).

\section{Methods}

The amount of noradrenaline and adrenaline in portal venous blood was estimated in 8 unselected patients undergoing portal venous decompression for portal hypertension. Control samples were also obtained from 8 patients with no known liver disease and without portal hypertension. In some of the patients blood from the inferior vena cava also was analysed for catechol amines. All patients were under general anæsthesia when the blood-samples were taken. The anæsthetic agents used were thiopentone sodium, nitrous oxide, cyclopropane, and innovan.

$60 \mathrm{ml}$. blood-samples were collected in heparinised syringes, refrigerated, and then centrifuged at 1500 r.p.m. for twenty-five minutes. The plasma was removed and placed in contact with $0.5 \mathrm{~g}$ of activated alumina in $10 \mathrm{ml}$. of $0.2 \mathrm{~N}$ sodium acetate, $0.5 \mathrm{ml}$. of $0.2 \mathrm{M}$ sodium edetate, and $2.0 \mathrm{ml}$. of $0.05 \mathrm{M}$ sodium thiosulphate. To check the method in each run, standards were added to one half of a divided plasma sample for internal recovery.

The samples were adjusted to $\mathrm{pH} 8.4$ for three minutes with constant stirring, and the alumina was separated chromatographically. The adsorbed catechol amines were eluted from the alumina with $6.5 \mathrm{ml}$. of $0.2 \mathrm{~N}$ acetic acid. A $3.0 \mathrm{ml}$. eluate fraction was then run as a sample for fluorometric determination. The trihydroxyindoles of adrenaline and noradrenaline in this sample were formed by oxidation with $0.1 \mathrm{ml}$. of an iodine solution (Crout 1962), in the presence of an ascorbate-bisulphate-hydroxide solution.

Blanks were prepared from the remaining $3.0 \mathrm{ml}$. eluate fraction by failing to add ascorbate and bisulphate to the alkaline oxidation mixture until the iodoaminochromes of the catechol amines had deteriorated. These fluorescent substances reach their highest concentration after about an hour, and the samples and blanks were read then on a 'Farrand' model A filter-fluorometer.

For the differential determination of noradrenaline and adrenaline, the samples and the standards were activated, and fuorescence was determined at two different wave-lengths (Cohen and Goldenberg 1957). Internal recoveries exceeded $70 \%$. No correction was made for incomplete recovery.

\section{Results}

In 7 of the 8 patients, the portal hypertension was secondary to hepatic cirrhosis-alcoholic or post-necrotic in origin-and in 1 (case 8) it was due to an extrahepatic block. The portal pressures in the 7 cirrhotic patients ranged from 205 to $460 \mathrm{~mm}$. of saline solution. None of the control patients had any clinical evidence of portal hypertension, and in none was there any suggestion of portal hypertension at operation. None had evidence of diffuse liver disease. Case 7 had what was believed to be a solitary hepatic metastasis in a site not accessible for biopsy, but the rest of his liver was grossly normal, and there was no laboratory evidence of diminished hepatic function.

The plasma values of adrenaline and noradrenaline in the portal venous blood of the portal hypertensive patients and the controls are shown in tables $I$ and II. No statistical difference was found between the portal venous catechol-amine content of patients with portal hypertension and that of the controls. Moreover, we could not confirm the finding of Shaldon et al. (1961, 1962) that in portal hypertension the level of catechol amines was much higher in the portal venous blood than in blood from the inferior vena cava.

The level of noradrenaline in the portal venous blood was slightly higher in all the patients in this group than the level in the systemic arterial plasma of 11 conscious, resting, cardiac patients with no liver disease or portal hypertension, and no evidence of myocardial decompensation (noradrenaline, $0 \cdot 32 \pm 0 \cdot 17 \mu \mathrm{g}$. per litre; adrenaline, $0.62 \pm 0.53 \mu \mathrm{g}$. per litre). This higher level of

TABLE I-CATECHOL AMINES IN NORMAL PORTAL BLOOD (Trihydroxyindole method)

\begin{tabular}{|c|c|c|c|c|}
\hline $\begin{array}{c}\text { Patient } \\
\text { no. }\end{array}$ & Sex & Diagnosis & $\begin{array}{l}\text { Noradrenaline } \\
\text { ( } \mu \mathrm{g} \text {. per litre) }\end{array}$ & $\begin{array}{c}\text { Adrenaline } \\
\text { ( } \mu \text { g. per litre) }\end{array}$ \\
\hline \multirow[t]{2}{*}{$\begin{array}{l}1 \\
2 \\
3 \\
4 \\
5 \\
6 \\
7 \\
8\end{array}$} & $\begin{array}{l}\mathrm{F} \\
\mathrm{F} \\
\mathrm{F} \\
\mathrm{M} \\
\mathrm{M} \\
\mathrm{F} \\
\mathrm{M} \\
\mathrm{F}\end{array}$ & $\begin{array}{c}\text { Cholecystitis* } \\
\text { " } " \\
\text { Cancer of stomach } \\
\text { Peptic ulcer } \\
\text { Cholecystitis } \\
\text { Cancer colon } \\
\text { Peptic ulcer }\end{array}$ & $\begin{array}{l}0.13 \\
0.80 \\
1.42 \\
0.42 \\
0.91 \\
1.40 \\
0.53 \\
0.43\end{array}$ & $\begin{array}{l}1.17 \\
0.40 \\
0.74 \\
1.13 \\
0.55 \\
0.59 \\
1.20 \\
0.28\end{array}$ \\
\hline & & & $0.75 \pm 0.50$ & $0.76 \pm 0.40$ \\
\hline
\end{tabular}

*Inferior vena cava values: noradrenaline, $0.66 \mu \mathrm{g}$. per litre; adrenaline, $1.20 \mu \mathrm{g}$. per litre. tSplanchnic arterial values: noradrenaline, $0.68 \mu \mathrm{g}$. per litre; adrenaline,
$0.80 \mu \mathrm{g}$. per litre.

noradrenaline in the portal venous blood than in systemic arterial plasma was found in one control patient (case 3), in whom the concentration of noradrenaline was determined in both the splanchnic arterial and portal venous blood. All patients had higher levels of plasma-adrenaline in the portal vein and inferior vena cava than the levels previously reported in peripheral venous blood (Cohen and Goldenberg 1957, Price and Price 1957, Vendsalu 1960). In view of the general anæsthesia and operative procedure each was undergoing when bloodsamples were taken this is not surprising (Price et al. 1960).

\section{Discussion}

Catechol amines are known to have adverse effects on the liver, producing fatty degeneration and necrosis (Wool et al. 1954, Butler et al. 1959, Brody and Calvert 1960, Calvert and Brody 1960, Brody et al. 1961). Adrena-

TABLE II-CATECHOL AMINES IN PORTAL HYPERTENSION (Trihydroxyindole method)

\begin{tabular}{|c|c|c|c|c|c|c|}
\hline \multirow[b]{2}{*}{$\begin{array}{c}\text { Patient } \\
\text { no. }\end{array}$} & \multirow[b]{2}{*}{ Sex } & \multirow[b]{2}{*}{ Diagnosis } & \multicolumn{2}{|c|}{ Portal vein } & \multicolumn{2}{|c|}{ Inferior vena cava } \\
\hline & & & $\begin{array}{l}\text { Noradren- } \\
\text { aline ( } \mu \mathrm{g} . \\
\text { per litre) }\end{array}$ & $\begin{array}{l}\text { Adren- } \\
\text { aline ( } \mu g . \\
\text { per litre) }\end{array}$ & $\begin{array}{l}\text { Noradren- } \\
\text { aline ( } \mu \mathrm{g} . \\
\text { per litre) }\end{array}$ & $\begin{array}{l}\text { Adren- } \\
\text { aline }(\mu \mathrm{g} . \\
\text { per litre) }\end{array}$ \\
\hline \multirow{6}{*}{$\begin{array}{l}1 \\
2 \\
3 \\
4 \\
5 \\
6 \\
7 \\
8\end{array}$} & \multirow{6}{*}{$\begin{array}{l}F \\
M \\
M \\
M \\
F \\
M \\
F \\
M\end{array}$} & \multirow{6}{*}{$\begin{array}{c}\text { Cirrhosis } \\
\text { ", } \\
" \\
" \\
" \\
\text { Extrah" } \\
\text { block }\end{array}$} & $0 \cdot 78$ & 0.85 & 1.9 & 0.24 \\
\hline & & & $\begin{array}{l}0.79 \\
0.48\end{array}$ & $\begin{array}{l}0.20 \\
0.62\end{array}$ & 0.99 & 0.00 \\
\hline & & & 0.76 & 0.00 & 0.77 & 0.00 \\
\hline & & & 0.43 & $0 \cdot 27$ & . & . \\
\hline & & & $\begin{array}{l}0.72 \\
0.67\end{array}$ & $\begin{array}{l}1.50 \\
0.67\end{array}$ & $0 \cdot 20$ & $1 \cdot 13$ \\
\hline & & & 0.05 & 0.09 & 0.85 & 0.75 \\
\hline & & & $0.58 \pm 0.22$ & $0.52 \pm 0.44$ & $\cdots$ & . \\
\hline
\end{tabular}


line increases portal venous pressure in normal man, but not in cirrhotics when there is an initial decrease in portal pressure (Child 1954). Decreases in blood-flow and organ volume in the portal system with catechol amines have been reported (Bayliss 1893, Jarisch and Ludwig 1926, Koch and Nordmann 1928, Gollwitzer-Meier and Schulte 1931, Heymans et al. 1931, Cannon and Rosenblueth 1933, Driver and Vogt 1950, Maegraith 1951). Recently Shaldon et al. (1961, 1962) have suggested that catechol amines play an important part in the pathogenesis of portal hypertension.

The values for portal venous catechol amines in portal hypertension reported by Shaldon and his coworkers were higher than those found by Cohen and Goldenberg (1957) in the peripheral venous blood of patients with phæochromocytoma, being at their highest more than twenty-five times higher than the highest phæochromocytoma values. Shaldon's normal values are more than ten times the values given in published reports (Cohen and Goldenberg 1957, Price and Price 1957, Vendsalu 1960). This suggests that Shaldon's results can be explained by a difference in method. The trihydroxyindole method of Lund (1941) as applied by Cohen and Goldenberg (1957) to the differential analysis of noradrenaline and adrenaline, which we used, has been shown to be specific for catechol amines, because the method requires that the compound to be detected must have a 3,4, dihydroxphenyl nycleus with a two carbon side-chain, a terminal nitrogen, and a hydroxyl group substituted on the $\beta$-carbon atom. This was confirmed by von Euler (1956).

Price and Price (1957) and Crout (1962) have shown further that, in addition to the lutines of noradrenaline and adrenaline, only the lutine of isopropyl noradrenaline has sufficient detectable fluoresence, and that neither dopamine, serotonin, nor the known precursors or breakdown products of noradrenaline or adrenaline significantly interfere with the analysis of catechol amines.

Siegel et al. 1961 have shown that the trihydroxyindole method is sensitive and accurate enough to measure the increase of catechol amines in the coronary veins produced by stimulation of the cardiac sympathetic nerves, and also that the chemical assay can be precisely correlated with the graded inotropic response of the heart. Also, Siegel and Gilmore (1960) have shown that the trihydroxyindole method is sufficiently sensitive to detect the reflex sympathetic release of catechol amines in baroreceptor activity resulting from hypotension. The repeatedly demonstrated specificity and sensitivity of the method makes it unlikely that an increase of the concentration of catechol amines in portal venous blood of the magnitude reported by Shaldon $(1961,1962)$ could have been overlooked. Possibly Shaldon's results are due to some other vasoactive principle (detectable by bioassay) in the portal venous blood of patients with portal hypertension.

Our own results throw no light on the role of catechol amines in the xtiology of cirrhosis of the liver. But, on the evidence of the specific trihydroxyindole test, we believe increased portal venous catechol amines are not responsible in man for the maintenance of the portal hypertension caused by cirrhosis of the liver or by extrahepatic portal block.

\section{Summary}

In a group of 8 unselected patients with portal hypertension and 8 patients with normal portal circulations the adrenaline and noradrenaline content of portal venous plasma was determined fluorometrically. No difference was found in the portal venous catechol amine content of these two groups.

We wish to express our appreciation to Dr. Charles G. Child, 3rd, for his interest and support of this investigation. Valuable technical assistance was provided by Mr. J. Diamond and Dr. Stephen Kukolja.

This work was carried out under grant HE-06790 from the National Heart Institute and U.S.P.H.S. grant HE-4260-05 and 05690 .

\section{REFERENCES}

Bayliss, W. M. (1893) F. Physiol. 14, 303.

Brody, T. M., Calvert, D. N. (1960) Amer. F. Physiol. 198, 682.

- Calvert, D. N., Schneider, A. F. (1961) F. Pharmacol 13, 341. Proc. 18, 374 .

Calvert, D. N., Brody, T. M. (1960) Amer. F. Physiol. 198, 669.

Cannon, W. B., Rosenblueth, A. (1933) ibid. 104, 557 .

Child, C. G. (1954) The Hepatic Circulation and Portal Hypertension,

Philadelphia.
Cohen, G., Goldenberg, M. (1957a) f. Neurochem. 2, 58.

- $(1957 \mathrm{~b})$ ibid. p. 71 . Crout, J. R. (1962) in Standard Methods of the American Association of
Clinical Chemistry; vol. 3 , New York.

Driver, R. L., Vogt, M. (1950) Brit. Y. Pharmacol. 5, 505.

Gollwitzer-Meier, K., Schulte, H. (1931) Pflug. Arch. ges. Physiol. 229, 264 eymans, C., Bouckaert, J. J., Dautrebande, L. (1931) Arch. int. Pharmacodyn. 40, 292

Jarisch, A., Ludwig, W. (1926) Arch. exp. Path. Pharmak. 114, 240

Koch, E., Nordmann, M. (1928) Z. KreislForsch. 20, 343.

Lund, A. (1941) Acta Pharm. Tox. Kbh. 5, 121.

McMichael, J. (1932) F. Physiol. 75, 241.

Maegraith, B. G. (1951) in Liver Injury: Transactions of Tenth Conference, May 21-22, Josiah Macy, Jr., Foundation.

Price, H. L., Price, M. L. (1957) F. Lab. clin. Med. 50, 769

- Linde, H. W., Price, M. L. (1960) Clin. Pharmacol. Therap. 1, 298 Siegel, J. H.; Gilmore, J. P., Sarnoff, S. J. (1961) Circulat. Res. 9, 1336. Shaldon (1960) Physiologist. 3, 166.

Shaldon, C. (1962) Ann. R. Coll. Surg. Engl. 31, 308.

- Peacock, J. H., Walker, R. M., Paimer, D., Budrick, F. (1961) Tisdale, W. A., Klatskin, G., Glenn, W. W. L. (1959) New Engl. f. Med. $261,202$.

Vendsalu, A. (1960) Acta physiol. scand. 49, suppl. 173.

Von Euler, U. S. (1956) Noradenaline. Sprinefield, Illinois, U.S.A.

Walder, D. N. (1952) Clin. Sci. 11, 59.

Wool, I. G., Goldstein, M. S., Ramey, E. R., Le sine, R. (1954) Amer. F. Phyviol. 178, 427.

\section{TWO APPARENTLY NORMAL TRIPLE-X FEMALES}

\author{
H. G. Close \\ M.D. Lond.
}

THE two cases of triple- $X$ females described here are of interest for several reasons. The sex-chromatin abnormalities were discovered during the examination of smears for malignant cells. In one case, double chromatin (Barr) bodies were noted in a vaginal smear, and in the other they were seen in the squamous cells of sputum. The patients are not (as in many of the published cases) mentally defective, and they do not have primary or secondary amenorrhœa. Furthermore, one of them (case 1) is fertile, like the triple- $\mathrm{X}$ females described by Stewart and Sanderson (1960), Fraser et al. (1960), and Lewis et al. (1963).

\section{Case 1}

A married woman of 37 attends a Family Planning Association clinic where it is the practice to examine smears for malignant cells from all patients over 30 . In her vaginal and cervical smears about $15 \%$ of the nuclei of the squamous cells showed two peripheral chromatin (Barr) bodies. Buccal smears showed the same percentage of nuclei with two chromatin bodies. Chromosome preparations of skin and peripheral leucocytes were made by the methods of Harnden (1960) and Moorhead et al. (1960). In each preparation the modal number of chromosomes was 47 . There was an additional chromosome in the 6-12 group, and in view of the buccal smear findings it is reasonable to assume that the additional chromosome is an X-chromosome and that the patient's sex-chromosome constitution is $\mathrm{XXX}$.

The patient is $5 \mathrm{ft} .7^{1 / 2}$ in. $(171 \mathrm{~cm}$.) tall and weighs $155 \mathrm{lb}$. $(70.3 \mathrm{~kg}$.$) . She is an only child and was born when her father$ 